\title{
KERAGAMAN KARAKTER AGRONOMI KLON-KLON F1 UBIKAYU (Manihot esculenta Crantz) KETURUNAN TETUA BETINA UJ-3, CMM 25-27, DAN MENTIK URANG
}

\author{
Diana Ika Putri, Sunyoto, Erwin Yuliadi \& Setyo Dwi Utomo* \\ Jurusan Agroteknologi, Fakultas Pertanian Universitas Lampung \\ J1.Prof. Soemantri Brodjonegoro, No.1 Bandar Lampung 35145 \\ E-mail:dianaikaputri@ymail.com \\ *Korespondensi:E-mail:setyo_du@unila.ac.id, telp (0721) 781820
}

\begin{abstract}
ABSTRAK
Penelitian bertujuan mengetahui keragaman karakter agronomi ubikayu (Manihot esculenta Crantz) klon-klon F1 keturunan tetua betina UJ-3, CMM 25-27, dan Mentik Urang. Genotipe yang dievaluasi meliputi berturut-turut 29, 40, dan 25 klon F1 keturunan tetua betina UJ-3, CMM 25-27, dan Mentik Urang. Klon-klon tersebut ditanam di Kelurahan Gedong Meneng, Kecamatan Rajabasa Kota Bandar Lampung, mulai bulan Juni 2011 sampai Maret 2012. Data dianalisis menggunakan statistika deskriptif untuk mengetahui nilai tengah, ragam, simpangan baku, dan dua kali simpangan baku. Hasil penelitian menunjukkan adanya keragaman warna pada variabel pucuk, tangkai atas, tangkai bawah, batang atas, batang bawah, kulit luar ubi (kecuali keturunan UJ-3), kulit dalam ubi (kecuali keturunan CMM 25-27 dan Mentik Urang), daging ubi (kecuali keturunan CMM 2527), jumlah lobus, dan cabang. Tingkat keragaman tinggi pada jumlah daun, panjang tangkai, panjang daun, tinggi tanaman, panjang ubi, bobot ubi, jumlah ubi (kecuali keturunan CMM 25-27), jumlah akar, bobot total dan indeks panen mengakibatkan seleksi menjadi lebih efektif. Sepuluh klon F1 hasil seleksi yaitu UJ-3-10, UJ-3-25, UJ-3-35, UJ-3-52, UJ-3-54, CMM 25-27-25, CMM 25-27-55, Mentik Urang 7, Mentik Urang 11, dan Mentik Urang 32.
\end{abstract}

Kata Kunci: keragaman, karakter agronomi, klon F1, singkong

\section{PENDAHULUAN}

Ubikayu (Manihot esculenta Crantz.) merupakan salah satu tanaman pangan daerah tropis yang tumbuh di Indonesia. Ubikayu dapat dimanfaatkan sebagai bahan pangan dan bahan baku berbagai macam industri. Produksi ubikayu Indonesia tahun 2011 sebesar 24 juta ton dengan areal seluas 1,18 juta ha. Sentra produksi ubikayu yaitu Lampung $(37,39 \%)$, selanjutnya Jawa Tengah (16,89\%), Jawa Timur (12,02\%), Jawa Barat $(9,07 \%)$, dan Sumatera Utara $4,46 \%$ (Dirjen Tanaman Pangan, 2012).

Pertumbuhan penduduk semakin meningkat tiap tahun, sehingga menyebabkan kebutuhan penduduk terhadap ubikayu juga semakin meningkat. Dengan demikian, Kementerian Pertanian mencanangkan program peningkatan produksi ubikayu melalui perluasan areal tanam dan peningkatan produtivitas (Saleh, 2007). Salah satu cara untuk meningkatkan produktivitas yaitu penggunaan varietas unggul.

Keberhasilan perakitan variets unggul ditentukan oleh tingkat keragaman plasma nutfah sebagai bahan dasar pemuliaan (Leon dkk. (2004) dan Zaidi dkk. (2003) dalam Wijayanto (2007)). Seleksi akan efektif jika tingkat keragaman tinggi sehingga peluang untuk mendapatkan varietas unggul lebih besar.

Tim Peneliti Unila, Yuliadi dan Utomo (2008) menyatakan bahwa klon Mulyo memiliki bobot ubi lebih tinggi daripada klon Kasesart, namun untuk tinggi tanaman sebaliknya. Mereka juga telah mengoleksi 8.000 benih botani hingga tahun 2010. Faroq (2011) telah mengevaluasi karakter agronomi klon-klon ubikayu di Prokimal, Lampung Utara. Aldiansyah dan Simatupang (2012) telah melakukan evaluasi karakter vegetatif dan generatif klon-klon ubikayu di Desa Muara Putih Natar Lampung Selatan yang menyatakan bahwa diantara 40 klon yang dievaluasi didapatkan 10 klon terbaik yaitu klon CMM 97-6, CMM 2-16, CMM 21-7, CMM 1-10, CMM 20-2, CMM 38-7, CMM 36-5, Duwet-3, Duwet1 dan Kelenteng. Dengan adanya 8.000 benih botani yang dikoleksi Yuliadi dan Utomo maka dapat dilakukan penelitian terhadap benih tersebut untuk mendapatkan varietas unggul yang diinginkan. Benih yang digunakan pada penelitian ini yaitu klon-klon F1 ubikayu keturunan tetua betina UJ-3, CMM 25-27, dan Mentik Urang. Penelitian ini bertujuan untuk mengetahui keragaman karakter agronomi klon-klon F1 ubikayu keturunan tetua betina UJ-3, CMM 25-27 dan Mentik Urang. 


\section{BAHAN DAN METODE}

Penelitian dilaksanakan di lahan petani di Kelurahan Gedong Meneng, Kecamatan Rajabasa Kota Bandar Lampung, mulai bulan Juni 2011 sampai Maret 2012. Bahan tanam yang digunakan adalah benih F1 ubikayu keturunan tetua betina UJ-3, CMM 25-27 dan Mentik Urang. Benih disemai di polybag berukuran 2 $\mathrm{kg}$ dengan perbandingan tanah dan pupuk kandang 1:1. Tanaman dipindahkan ke lahan tanam yang berjarak 30 $\mathrm{cm}$ x $30 \mathrm{~cm}$. Pemupukan berupa pupuk kandang dosis 3 $\mathrm{kg} / \mathrm{m}^{2}$, pupuk NPK dengan dosis $52 \mathrm{~g} /$ tanaman, dan pupuk urea dengan dosis $27 \mathrm{~g}$ per lubang tanam.

Penelitian dilakukan tanpa ulangan. Pengamatan warna dilakukan secara visual berdasarkan Daftar Deskriptor Data Karakter Ubikayu (Balai Besar Penelitian dan Pengembangan Bioteknologi dan Sumberdaya Genetik Pertanian, 2010). Data dianalisis dengan metode statistik deskriptif. Persentase digunakan untuk karakter kualitatif, sedangkan nilai maksimum, nilai minimum, kisaran, nilai tengah, ragam, simpangan baku, dan dua kali simpangan baku untuk karakter kuantitatif. Rumus yang digunakan yaitu (Walpole, 1995):

1. Nilai tengah

$$
\mu=\frac{\sum X_{i}}{N}
$$

2. Ragam

$$
\sigma^{2}=\frac{\sum_{i=1}^{N}\left(X_{i}-\mu\right)^{2}}{N}
$$

3. Simpangan baku

$$
\sigma=\sqrt{\sigma^{2}}
$$

Jika nilai ragam lebih besar dari dua kali simpangan baku maka disimpulkan tingkat keragaman luas, sedangkan jika nilai ragam lebih kecil dari dua kali simpangan baku maka keragaman sempit (Pinaria $d k k$., 1995 dalam Rostini $d k k$., 2006). Karakter kuantitatif diurutkan dari peringkat tertinggi hingga terendah. Indeks panen, jumlah ubi, bobot ubi, jumlah daun, dan tinggi tanaman digunakan untuk memilih 10 klon harapan dari klon-klon yang dimati. Variabel tersebut mempunyai korelasi terhadap hasil produksi sehingga dapat dijadikan tolok ukur produksi ubi.

\section{HASIL DAN PEMBAHASAN}

Keragaman genotipe-genotipe yang terdapat di dalam plasma nutfah ubikayu dicirikan oleh warna, ukuran daun, batang maupun ubinya (CIAT (1983) dalam Zuraida (2010)). Hal ini didukung Eathington (1997) dalam Wijayanto (2007) bahwa pengamatan terhadap warna bagian tanaman ubikayu tergolong karakterisasi kualitatif yang dapat digunakan sebagai penciri, sebab karakter tersebut hanya dikendalikan oleh satu atau sejumlah kecil gen sehingga pengaruh lingkungan sangat kecil dan mudah diwariskan pada keturunannya.

Apabila suatu populasi tanaman ditanam pada kondisi lingkungan yang sama, maka keragaman tanaman yang muncul disebabkan perbedaan susunan genetik jika faktor lain bersifat konstan. Keragaman fenotipe tanaman akibat perbedaan susunan genetik selalu mungkin terjadi sekalipun bahan tanam yang digunakan berasal dari jenis tanaman yang sama (Sitompul dan Bambang, 1995). Adanya gen-gen tetua yang bersifat heterozigot maka dapat menghasilkan keturunan yang beragam. Warna pucuk keturunan UJ3 terdiri atas hijau, hijau muda dan hijau kecoklatan (Tabel 1). Keturunan yang dihasilkan berupa tipe rekombinan (hijau dan hijau kecoklatan) dan tipe parental (hijau muda). Keturunan yang memiliki tipe rekombinan merupakan gamet tipe baru hasil dari pindah silang sedangkan tipe parental memiliki gen seperti tetuanya. Demikian pula dengan warna batang atas, batang bawah, tangkai atas, tangkai bawah, kulit luar, kulit dalam dan daging ubi (Tabel 2, 3, 4, 5, 6, 7, dan 8). Susunan genetik yang berbeda tidak selalu seluruhnya diekspresikan (Sitompul dan Bambang, 1995). Warna daging ubi keturunan tetua betina CMM 25-27 dari 10 klon tanaman yang diamati seluruhnya berwarna putih (Tabel 8), namun belum tentu susunan genetik setiap klon sama. Adanya genotipe yang bersifat heterozigot dominan maka gen-gen resesif warna lain tidak terlihat.

Percabangan erat kaitannya dengan pembentukan bunga (Cock, 1983 dalam Goldsworthy dan Fisher, 1996) sebab pembungaan hanya terjadi pada setiap ketiak percabangan (Wargiono, 1997). Menurut Aldiansyah (2012), semakin banyak tanaman ubikayu yang bercabang maka semakin besar peluang untuk menghasilkan biji. Keturunan tetua betina UJ-3, CMM 25-27, dan Mentik Urang ada yang memiliki jumlah cabang 2 dan 3 meskipun didominasi dengan klon yang tidak memiliki cabang (Tabel 9). Tanaman bercabang memiliki jumlah daun yang banyak sehingga terdapat korelasi antara percabangan, jumlah daun, lebar dan panjang lobus daun (Tabel 10).

Menurut Wargiono (1979) semakin banyak jumlah daun maka ubi yang dihasilkan pun semakin banyak akibat adanya aktivitas fotosintesis yang tinggi. Selain itu, jumlah lobus juga berpengaruh pada fotosintesis. Menurut Zuraida (2010), semakin banyak lobus pada 
Tabel 1.Warna pucuk klon-klon ubikayu keturunan UJ-3, CMM 25-27 dan Mentik Urang

\begin{tabular}{lcccccc}
\hline \multirow{2}{*}{ Warna pucuk } & \multicolumn{2}{c}{ UJ-3 } & \multicolumn{2}{c}{ CMM 25-27 } & \multicolumn{2}{c}{ Mentik Urang } \\
\cline { 2 - 7 } & Jumlah klon & $(\%)$ & Jumlah klon & $(\%)$ & Jumlah klon & $(\%)$ \\
\hline Hijau muda & 10 & 34,48 & 10 & 25 & 14 & 56 \\
Merah & - & - & - & - & 2 & 8 \\
Hijau kecoklatan & 7 & 24,14 & 25 & 62,5 & 7 & 28 \\
Hijau & 12 & 41,38 & 5 & 12,5 & 2 & 8 \\
\hline Tetua betina & \multicolumn{3}{c}{ hijau muda } & \multicolumn{3}{c}{ Hijau } \\
\hline
\end{tabular}

Tabel 2.Warna batang atas klon-klon ubikayu keturunan UJ-3, CMM 25-27 dan Mentik Urang

\begin{tabular}{lcccccc}
\hline \multirow{2}{*}{ Warna batang atas } & \multicolumn{2}{c}{ UJ-3 } & \multicolumn{2}{c}{ CMM 25-27 } & \multicolumn{2}{c}{ Mentik Urang } \\
\cline { 2 - 7 } & Jumlah klon & $(\%)$ & Jumlah klon & $(\%)$ & Jumlah klon & $(\%)$ \\
\hline Hiijau & 27 & 93,10 & 25 & 62,50 & 14 & 56 \\
Hijau tua & 1 & 3,45 & 3 & 7,50 & 1 & 4 \\
Hijau kemerahan & 1 & 3,45 & 12 & 30 & 10 & 40 \\
\hline Tetua betina & \multicolumn{3}{c}{ Hijau } & \multicolumn{3}{c}{ hijau tua } \\
\hline
\end{tabular}

Tabel 3.Warna batang bawah klon-klon ubikayu keturunan UJ-3, CMM 25-27, dan Mentik Urang

\begin{tabular}{lcccccc}
\hline \multirow{2}{*}{ Warna batang bawah } & \multicolumn{2}{c}{ UJ-3 } & \multicolumn{2}{c}{ CMM 25-27 } & \multicolumn{2}{c}{ Mentik Urang } \\
\cline { 2 - 7 } & Jumlah klon & $(\%)$ & Jumlah klon & $(\%)$ & Jumlah klon & $(\%)$ \\
\hline Gading & 9 & 31,03 & 9 & 22,50 & 12 & 48 \\
Abu-abu & 20 & 68,97 & 31 & 77,50 & 11 & 44 \\
Merah & \multicolumn{2}{c}{ abu-abu } & - & \multicolumn{2}{c}{ abu-abu } & - \\
\hline Tetua betina & \multicolumn{2}{c}{ aberah } \\
\hline
\end{tabular}

Tabel 4. Warna tangkai atas klon-klon ubikayu keturunan UJ-3, CMM 25-27 dan Mentik Urang

\begin{tabular}{lcccccc}
\hline \multirow{2}{*}{ Warna tangkai atas } & \multicolumn{2}{c}{ UJ-3 } & \multicolumn{2}{c}{ CMM 25-27 } & \multicolumn{2}{c}{ Mentik Urang } \\
\cline { 2 - 7 } & Jumlah klon & $(\%)$ & Jumlah klon & $(\%)$ & Jumlah klon & $(\%)$ \\
\hline Hijau & 3 & 10,34 & 2 & 5 & 3 & 12 \\
Hijau kemerahan & 17 & 58,62 & 8 & 20 & 7 & 28 \\
Merah & 1 & 3,45 & 21 & 52,50 & 9 & 36 \\
Merah kehijauan & 8 & 27,59 & 9 & 22,50 & 6 & 24 \\
\hline Tetua betina & \multicolumn{3}{c}{ hijau kemerahan } & \multicolumn{3}{c}{ Merah } \\
\hline
\end{tabular}

Tabel 5.Warna tangkai bawah klon-klon ubikayu keturunan UJ-3, CMM 25-27 dan Mentik Urang

\begin{tabular}{lcccccc}
\hline \multirow{2}{*}{ Warna tangkai bawah } & \multicolumn{2}{c}{ UJ-3 } & \multicolumn{2}{c}{ CMM 25-27 } & \multicolumn{2}{c}{ Mentik Urang } \\
\cline { 2 - 7 } & Jumlah klon & $(\%)$ & Jumlah klon & $(\%)$ & Jumlah klon & $(\%)$ \\
\hline Hijau & 27 & 93,10 & 15 & 37,5 & 14 & 56 \\
Hijau kemerahan & 1 & 3,45 & 21 & 52,5 & 2 & 8 \\
Merah & - & - & 2 & 5 & 7 & 28 \\
Merah kehijauan & 1 & 3,45 & 2 & 5 & 2 & 8 \\
\hline Tetua betina & \multicolumn{3}{c}{ Hijau } & \multicolumn{3}{c}{ Hijau } \\
\hline
\end{tabular}


Tabel 6. Warna kulit luar ubikayu keturunan UJ-3, CMM 25-27 dan Mentik Urang

\begin{tabular}{lcccccc}
\hline \multirow{2}{*}{ Warna kulit luar ubi } & \multicolumn{2}{c}{ UJ-3 } & \multicolumn{2}{c}{ CMM 25-27 } & \multicolumn{2}{c}{ Mentik Urang } \\
\cline { 2 - 7 } & Jumlah klon & $(\%)$ & Jumlah klon & $(\%)$ & Jumlah klon & $(\%)$ \\
\hline Coklat muda & 10 & 100 & 6 & 60 & 7 & 77,77 \\
Coklat & - & - & 4 & 40 & 2 & 22,22 \\
\hline Tetua betina & \multicolumn{2}{c}{ coklat muda } & \multicolumn{2}{c}{ coklat muda } & \multicolumn{2}{c}{ coklat muda } \\
\hline
\end{tabular}

Tabel 7. Warna kulit dalam klon-klon ubikayu keturunan UJ-3, CMM 25-27 dan Mentik Urang

\begin{tabular}{lcccccc}
\hline \multirow{2}{*}{ Warna kulit dalam ubi } & UJ-3 & \multicolumn{2}{c}{ CMM25-27 } & \multicolumn{2}{c}{ Mentik Urang } \\
\cline { 2 - 7 } & Jumlah klon & $(\%)$ & Jumlah klon & $(\%)$ & Jumlah klon & $(\%)$ \\
\hline Gading & 8 & 80 & 10 & 100 & 9 & 100 \\
Kuning & 2 & 20 & - & - & - & - \\
\hline Tetua betina & Gading & \multicolumn{2}{c}{ Gading } & \multicolumn{2}{c}{ Gading } \\
\hline
\end{tabular}

Tabel 8. Warna daging klon-klon ubikayu keturunan UJ-3, CMM 25-27 dan Menti kUrang

\begin{tabular}{|c|c|c|c|c|c|c|}
\hline \multirow{2}{*}{ Warna daging ubi } & \multicolumn{2}{|c|}{ UJ-3 } & \multicolumn{2}{|c|}{ CMM 25-27 } & \multicolumn{2}{|c|}{ Mentik Urang } \\
\hline & Jumlah klon & $(\%)$ & Jumlah klon & $(\%)$ & Jumlah klon & $(\%)$ \\
\hline Putih & 8 & 80 & 10 & 100 & 7 & 77,77 \\
\hline Kuning & 2 & 20 & - & - & 2 & 22,22 \\
\hline Tetua betina & \multicolumn{2}{|c|}{ Putih } & \multicolumn{2}{|l|}{ Putih } & \multicolumn{2}{|c|}{ Putih } \\
\hline
\end{tabular}

Tabel 9. Jumlah cabang klon-klon ubikayu keturunan UJ-3, CMM 25-27 dan Mentik Urang

\begin{tabular}{ccccccc}
\hline \multirow{2}{*}{ Jumlah cabang } & \multicolumn{2}{c}{ UJ-3 } & \multicolumn{3}{c}{ CMM 25-27 } & \multicolumn{2}{c}{ Mentik Urang } \\
\cline { 2 - 7 } & Jumlah klon & $(\%)$ & Jumlah klon & $(\%)$ & Jumlah klon & $(\%)$ \\
\hline 3 & 2 & 6,90 & 1 & 2,5 & 5 & 20 \\
2 & 3 & 10,34 & 5 & 12,5 & 4 & 16 \\
0 & 24 & 82,76 & 34 & 85 & 16 & 64 \\
\hline
\end{tabular}

Tabel 10. Jumlah lobus klon-klon ubikayu keturunan UJ-3, CMM 25-27 dan Mentik Urang

\begin{tabular}{ccccccc}
\hline \multirow{2}{*}{ Jumlah lobus } & \multicolumn{2}{c}{ UJ-3 } & \multicolumn{2}{c}{ CMM 25-27 } & \multicolumn{2}{c}{ Mentik Urang } \\
\cline { 2 - 7 } & Jumlah klon & $(\%)$ & Jumlah klon & $(\%)$ & Jumlah klon & $(\%)$ \\
\hline 9 & 2 & 6,89 & 9 & 22,5 & 3 & 12 \\
7 & 19 & 65,52 & 28 & 70 & 17 & 68 \\
5 & 7 & 24,14 & 3 & 7,5 & 4 & 16 \\
3 & 1 & 3,45 & - & - & 1 & 4 \\
\hline
\end{tabular}

tanaman ubikayu maka semakin banyak fotosintat yang diberikan ke ubi. Korelasi antar karakter dapat digunakan sebagai alat untuk menentukan seleksi tidak langsung. Seleksi tidak langsung dianggap lebih efektif dibandingkan dengan seleksi langsung jika korelasi antara karakter yang diteliti tersebut sangat kuat (Kearsey dan Pooni, 1996 dalam Rostini dkk., 2006).

\section{Karakter Kuantitatif}

Secara umum, proses pertumbuhan dan perkembangan dari berbagai jenis tanaman tidak terlalu berbeda. Namun, kandungan total DNA antara tanaman beragam (Siregar, 2002). Hal ini terlihat dari pertumbuhan karakter kuantitatif klon-klon F1 ubikayu keturunan UJ-3, CMM 25-27, dan Mentik Urang yang 
berbeda menyatakan adanya keragaman (Tabel 11, 12, dan 13).

Menurut Martono (2011), keragaman genetik yang luas berarti terdapat genotipe yang berbeda dalam suatu populasi. Genotipe-genotipe yang bersifat herezigot melakukan penyerbukan sehingga keturunan yang dihasilkan beragam. Pendapat ini didukung Rachmadi (2000) bahwa persilangan antardua tetua yang memiliki latar belakang genetik yang heterozigot sehingga keturunan yang dihasilkan bersegregasi.

Zen (2002) dalam Reny dkk. (2009) menyatakan bahwa untuk mencapai tujuan seleksi harus diketahui antarkarakter agronomi, komponen hasil dan hasil, sehingga seleksi terhadap satu karakter atau lebih dapat dilakukan. Menurut Marlitasari (2012), keragaman genetik umumnya cukup besar pada tanaman

Tabel 11. Karakter kuantitatif klon-klon ubikayu keturunan tetua betina UJ-3

\begin{tabular}{llllllll}
\hline Variabel & Nilai min & Nilai maks & Nilai tengah & Ragam $(\sigma 2)$ & SB $(\sigma)$ & 2 x SB $(\%)$ & Kriteria \\
\hline JD & 11 & 117 & 47,75 & 598,53 & 24,46 & 48,92 & Luas \\
PT $(\mathrm{cm})$ & 8,90 & 30 & 21,96 & 33,33 & 5,77 & 11,54 & Luas \\
PD $(\mathrm{cm})$ & 5 & 20,50 & 14,78 & 13,82 & 3,72 & 7,44 & Luas \\
LD $(\mathrm{cm})$ & 2 & 5,50 & 3,83 & 0,92 & 0,96 & 1,92 & Sempit \\
TT $(\mathrm{cm})$ & 37,50 & 170,80 & 116,28 & $1.344,06$ & 36,66 & 73,32 & Luas \\
DB $(\mathrm{cm})$ & 0,53 & 1,63 & 1,10 & 0,14 & 0,37 & 0,74 & Sempit \\
PU (cm) & 11,73 & 23,00 & 14,56 & 12,09 & 3,48 & 6,95 & Luas \\
DU (cm) & 2,83 & 6,23 & 4,44 & 1,06 & 1,03 & 2,06 & Sempit \\
BU (g) & 240 & 2.280 & 814 & 310924 & 557,60 & $1.115,21$ & Luas \\
JU & 2 & 10 & 4,1 & 5,09 & 2,25 & 4,50 & Luas \\
JA & 2 & 11 & 5,7 & 8,61 & 2,93 & 5,86 & Luas \\
BT $(\mathrm{g})$ & 540 & 3.830 & 1.712 & 908.656 & 953,23 & $1.906,46$ & Luas \\
IP $(\%)$ & 21,74 & 73,81 & 48,36 & 254,94 & 15,96 & 31,92 & Luas \\
\hline
\end{tabular}

Keterangan: JD (Jumlah daun), Pt (Panjang tangkai), PD (Panjang lobus daun), LD ( Lebar lobus daun),TT (Tinggi tanaman), DB (Diameter batang), PU (Panjang ubi), DU (Diameter ubi), BU (Bobot ubi), JU (Jumlah ubi), JA (Jumlah akar), BT (Bobot total), IP (Indeks panen).

Tabel 12. Karakter kuantitatif klon-klon ubikayu keturunan CMM 25-27

\begin{tabular}{llllllll}
\hline Variabel & Nilai min & Nilai maks & Nilai tengah & Ragam $(\sigma 2)$ & SB $(\sigma)$ & 2 x SB $(\%)$ & Kriteria \\
\hline JD & 11 & 91 & 50,60 & 398,59 & 19,96 & 39,93 & Luas \\
PT $(\mathrm{cm})$ & 10,60 & 38,50 & 29,55 & 34,71 & 5,89 & 11,78 & Luas \\
PD $(\mathrm{cm})$ & 9,90 & 24,40 & 16,89 & 13,38 & 3,66 & 7,32 & Luas \\
LD $(\mathrm{cm})$ & 3,20 & 5,90 & 4,62 & 0,70 & 0,84 & 1,67 & Sempit \\
TT $(\mathrm{cm})$ & 39,70 & 253,90 & 163,50 & $3.161,50$ & 56,23 & 112,45 & Luas \\
DB $(\mathrm{cm})$ & 0,43 & 1,96 & 1,30 & 0,22 & 0,47 & 0,94 & Sempit \\
PU $(\mathrm{cm})$ & 2,75 & 31,33 & 13,34 & 57,48 & 7,58 & 15,16 & Luas \\
DU $(\mathrm{cm})$ & 1,60 & 4,83 & 3,04 & 0,74 & 0,86 & 1,72 & Sempit \\
BU $(\mathrm{g})$ & 50 & 840 & 321 & 59.009 & 242,92 & 485,84 & Luas \\
JU & 1 & 5 & 3,40 & 1,64 & 1,28 & 2,56 & Sempit \\
JA & 3 & 24 & 11,70 & 28,81 & 5,37 & 10,73 & Luas \\
BT $(\mathrm{g})$ & 130 & 2.790 & $1.090,20$ & 912.372 & 955,18 & $1.910,36$ & Luas \\
IP $(\%)$ & 19,50 & 74,36 & 35,76 & 303,17 & 17,41 & 34,82 & Luas \\
\hline
\end{tabular}


Tabel 13. Karakter kuantitatif klon-klon ubikayu keturunan Mentik Urang

\begin{tabular}{llllllll}
\hline Variabel & Nilai min & Nilai maks & Nilai tengah & Ragam $(\sigma 2)$ & SB $(\sigma)$ & 2 x SB $(\%)$ & Kriteria \\
\hline JD & 13 & 89 & 37,20 & 523,60 & 22,88 & 45,76 & Luas \\
PT $(\mathrm{cm})$ & 11,80 & 34,50 & 23,37 & 52,83 & 7,27 & 14,54 & Luas \\
PD $(\mathrm{cm})$ & 6,70 & 27,00 & 15,28 & 28,19 & 5,31 & 10,62 & Luas \\
LD $(\mathrm{cm})$ & 2,10 & 6,30 & 4,22 & 1,36 & 1,17 & 2,33 & Sempit \\
TT $(\mathrm{cm})$ & 38 & 167,80 & 102 & 1385,76 & 37,23 & 74,45 & Luas \\
DB $(\mathrm{cm})$ & 0,30 & 1,83 & 0,94 & 0,19 & 0,43 & 0,86 & Sempit \\
PU $(\mathrm{cm})$ & 6,20 & 21,35 & 14,44 & 18,85 & 4,34 & 8,68 & Luas \\
DU $(\mathrm{cm})$ & 2,70 & 7,40 & 4,79 & 2,35 & 1,53 & 3,06 & Sempit \\
BU $(\mathrm{g})$ & 50 & 1,500 & 608,89 & 230432,10 & 480,03 & 960,06 & Luas \\
JU & 1 & 7 & 4 & 5,11 & 2,26 & 4,52 & Luas \\
JA & 0 & 12 & 6 & 18,22 & 4,26 & 8,52 & Luas \\
BT $(\mathrm{g})$ & 560 & 2200 & 1360 & 445955,56 & 667,79 & 1335,58 & Luas \\
IP $(\%)$ & 5,68 & 68,18 & 42,54 & 387,78 & 19,69 & 39,38 & Luas \\
\hline
\end{tabular}

menyerbuk silang dibandingkan dengan tanaman menyerbuk sendiri sehingga dalam menentukan kriteria seleksi diutamakan pada sifat ekonomi terlebih dahulu, dalam hal ini bobot ubi. Sedangakan Rachmadi (2000) menyatakan bahwa hasil dapat diduga melalui karakterkarakter lain yang berkorelasi dengan karakter hasil yang dinamakan seleksi tidak langsung. Indeks panen merupakan tolok ukur dari produktivitas tanaman ubikayu. Nilai indeks panen rendah $(<50 \%)$ menunjukkan tanaman tersebut tidak produktif (Minantyorini dkk., 1993). Zuraida (2010) menyatakan bahwa tinggi tanaman, jumlah ubi, bobot brangkasan, dan indeks panen memiliki korelasi positif dengan bobot ubi, sedangkan diameter batang dan karakter lobus tidak berkorelasi dengan ubi.

Berdasarkan indeks panen, bobot ubi, jumlah ubi, jumlah daun, dan tinggi tanaman didapat 10 klon harapan yaitu: UJ-3-10, UJ-3-25, UJ-3-35, UJ-3-52, UJ-3-54, CMM 25-27-25, CMM 25-27-55, Mentik Urang 7, Mentik Urang 11, dan Mentik Urang 32.

\section{KESIMPULAN}

Karakter kualitatif pada keturunan UJ-3, CMM 25-27 dan Mentik Urang sangat beragam yang ditunjukkan dengan adanya perbedaan warna pucuk, tangkai atas, tangkai bawah, batang atas, batang bawah, warna kulit luar ubi (kecuali keturunan UJ-3), warna kulit dalam ubi (kecuali keturunan CMM 25-27 dan Mentik Urang), warna daging ubi (kecuali keturunan CMM 25-27), jumlah lobus, dan jumlah cabang.
Karakter kuantitatif keturunan UJ-3, CMM 2527, dan Mentik Urang memiliki keragaman luas meliputi: jumlah daun, panjang tangkai, panjang daun, tinggi tanaman, panjang ubi, bobot ubi, jumlah ubi (kecuali keturunan CMM 25-27), jumlah akar, bobot total dan indeks panen.

Sepuluh klon-klon harapan dari keturunan UJ-3, CMM 25-27 dan Mentik Urang yaitu: UJ-3-10, UJ-325, UJ-3-35, UJ-3-52, UJ-3-54, CMM 25-27-25, CMM 25-27-55, Mentik Urang 7, Mentik Urang 11, dan Mentik Urang 32 .

\section{UCAPAN TERIMA KASIH}

Penelitian ini sebagian dibiayai oleh Indonesia Managing Higher Education for Relevance and Efficiency (IMHERE) tahun 2011 dan Hibah Bersaing Ditjen Dikti (Desentralisasi) tahun 2012.

\section{DAFTAR PUSTAKA}

Aldiansyah. 2012. Evaluasi Karakter Vegetatif Klonklon Ubikayu (Manihot esculenta Crantz) di Desa Muara Putih Kecamatan Natar Lampung Selatan. Skripsi. Bandar Lampung: Universitas Lampung. $101 \mathrm{hlm}$.

Balai Besar Penelitian dan Pengembangan Bioteknologi dan Sumberdaya Genetik Pertanian. 2011. Daftar Deskriptor Data Karakter Ubikayu. http:// biogen.litbang.deptan.go.id/plasmanutfah/ engines/character_pdf. 12 Januari 2012. 
Direktorat Jenderal Tanaman Pangan. 2011. Luas Tanam, Luas Panen, Produktivitas, dan Produksi Ubikayu (ARAM II 2011). http:// tanamanpangan.deptan.go.id/doc_upload/ Luas\%20Tanam, \%20Luas\%20Panen, $\% 20$ Produktifitas $\% 20 \& \% 20 P$ roduksi\% 20Ubi\%20Kayu\%20(Aram\%20II\%202011).pdf. 28 Agustus 2012.

Faroq, D. I. 2011. Evaluasi karakter agronomi klonklon ubikayu (Manihot esculenta Crantz) di Prokimal Lampung Utara. (Skripsi). Program Studi Agronomi, Jurusan Budidaya Pertanian, Fakultas Pertanian Unila: Bandar Lampung. 100 hlm.

Goldsworthy, P. R. dan N. M. Fisher. 1996. Fisiologi Tanaman Budidaya Tropik. Yogyakarta: Gadjah Mada University Press.

Marlitasari, E. 2012. Makalah Menyerbuk Silang Tanaman Alpukat.http://blog.ub.ac.id/ervianii/ 2012/06/25/makalah-menyerbuk-silang-tanamanalpukat/. 2 Agustus 2012.

Martono, B. 2011. Keragaman Genetik, Heritabilitas dan Korelasi antar Karakter kuantitatif nilam (Pogestemon sp.) Hasil Fusi Protoplas. Jurnal Litri 15(1): 9-15.

Minantyorini, N. Zuraida, dan A. Dimyati. 1993. Penampilan Sifat-sifat Utama pada Seleksi Lanjut Klon-klon Ubikayu. Risalah Hasil Penelitian Tanaman Pangan 3:11-15.

Rachmadi, M. 2000. Pengantar Pemuliaan Tanaman Membiak Vegetatif. Bandung: Universitas Padjajaran. $159 \mathrm{hlm}$.

Reny, H., B. S. Purwoko dan I. S. Dewi. 2009. Keragaman Genetik dan Karakter Agronomi Galur Haploid Ganda Padi Gogo dengan SifatSifatTipe Baru Hasil Kultur Antera. J. Agron. Indonesia 37 (2) : 87 -94.

Rostini, N., Y Giametri, S. Amien. 2006. Korelasi Hasil dan Komponen Hasil dengan Kualitas Hasil pada 100 Genotip Nenas (Ananas comosus (1.) Merr.) dari Beberapa Seri Persilangan Generasi F1. Zuriat 2 (XVII):103-113.
Saleh, N. 2007. Tekonologi Produksi Ubikayu Mendukung Ketahanan Pangan dan Agroindustri. www.puslittan.bogor.net. 22 Oktober 2011.

Simatupang, D. 2012. Evaluasi Karakter Generatif Klon-klon Ubikayu (Manihot esculenta Crantz) di Desa Muara Putih Kecamatan Natar Lampung Selatan. Skripsi. Universitas Lampung: Bandar Lampung. 83 hlm.

Siregar, E. B. M. 2002. Proses-proses Awal Ekspresi Gen pada Tanaman. USU Digital Library. http:/ /repository.usu.ac.id/bitstream/123456789/ 895/1/hutan-edy2.pdf. 29 Agustus 2012.

Sitompul, S. M. dan Bambang Guritno. 1995. Analisis Pertumbuhan Tanaman. Gadjah Mada Universitas Press: Yogyakarta. $412 \mathrm{hlm}$.

Wargiono. 1979. Ubikayu dan Cara Bercocok Tanamnya. Lembaga Pusat Penelitian Pertanian Bogor : Bogor. Hlm 12 - 26.

Wijayanto, T. 2007. Karakteristik Sifat-sifat Agronomi Beberapa Nomor Koleksi Sumberdaya Genetik Jagung Sulawesi. Jurnal Penelitian dan Informasi Pertanian Agrin.

Yuliadi, E., dan S. D. Utomo. 2008. Pengujian Dua Varietas Ubikayu (Manihot utilissima Pohl) pada Dua Kepadatan Populasi Tanam yang Berbeda dalam Pola Tanam Tumpangsari Dengan Jagung. DIPA PNBP Universitas Lampung. Diakses 26 agustus 2012. http:// repository.unila.ac.id:8180/dspace/bitstream/ $123 \quad 4 \quad 566789 / 256 / 1 /$ 2008_LP_LP_YULIADI_l.pdf

Zuraida, N. 2010. Karakterisasi Beberapa Sifat Kualitatif dan Kuantitatif Plasma Nutfah Ubi Kayu (Manihot esculenta Crantz.). Buletin Plasma Nutfah 16 (1):49-56. 